FIGURE 1.

Expected Hires for Subsequent Year by Type of Institution

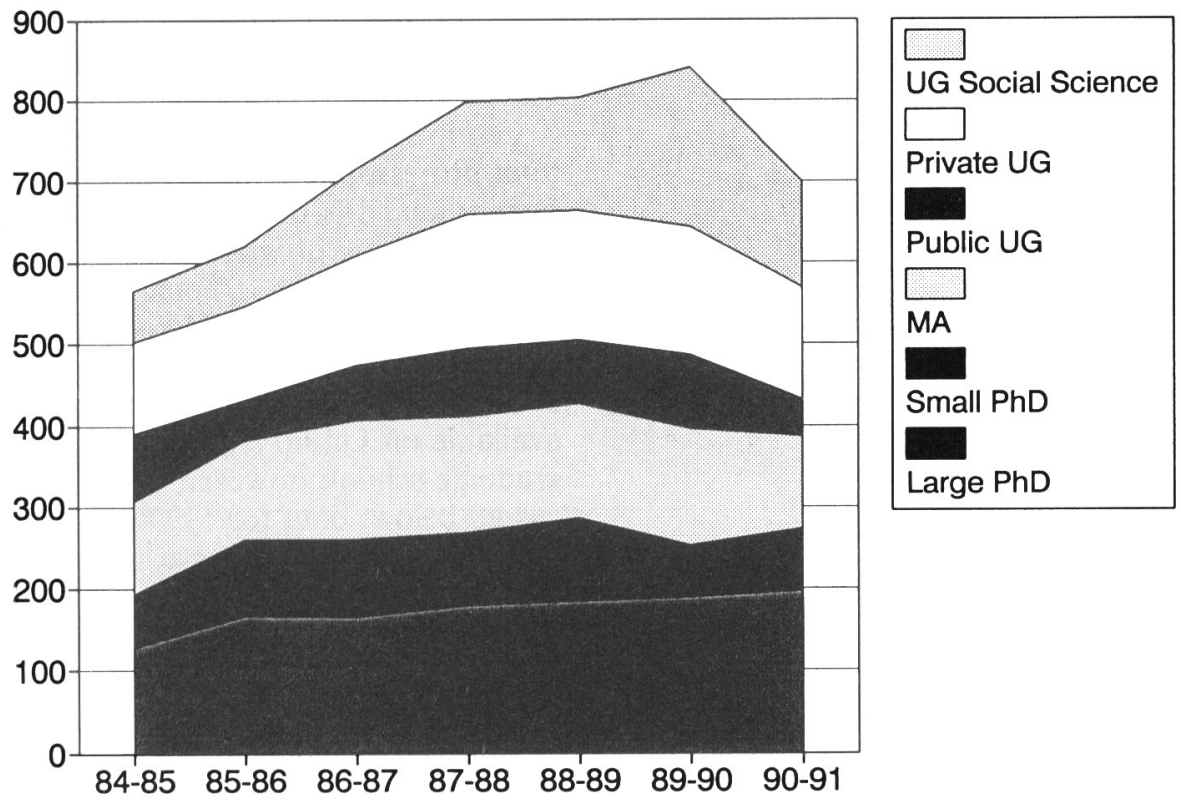

Source: APSA Departmental Survey

\section{Prospects for the Future}

Much evidence in recent years has suggested that cautious optimism about future job prospects in political science is warranted. The enrollment and hiring picture in the discipline has been strong (as reported in the last placement report, $P S, 1990$ ). And this placement report offers no discouraging evidence.

Similar findings have emerged in other academic disciplines. In 1990, the Chronicle of Higher Education reported that colleges were having trouble filling vacancies, and that associations representing many academic disciplines are listing increasing numbers of new openings (Blum, 1990). However, since these placement data were gathered, many public and private institutions have had to confront budget cuts. While the political science job market has not suffered to date, because, in part, of continued growth in student enrollments, there is evidence the profession will begin to feel these financial constraints.

Figure 1 shows levels of expected hiring for the following academic year reported in the annual Departmental Survey from AY 1984-85 through last year. Expectations expressed last year for hiring this year are down from the highs of the last two years-especially in M.A. departments, public undergraduate departments, and small departments where political science is combined with other disciplines. Expected hiring at Ph.D. schools is reported steady.

In a later 1992 issue of $P S$, I will report on the trend in the number and types of job listings as recorded in The Personnel Service Newsletter and the Placement Service in 1991-92 by way of gathering data on the immediate impact of the recession on the job market for political scientists. Nonetheless, the expectation of a good job market from 1997 to 2002, due to a shortfall of faculty because of impending retirements and expanding enrollments, remains (Bowen and Sosa, 1989).

Blum, Debra. 1990. "Job Market Begins Predicted Turnaround, Survey Indicates: Many Colleges Find It Difficult to Fill Faculty Vacancies." The Chronicle of Higher Education, July 25, p. A1.

Bowen, William G. and Julie Ann Sosa. 1989. Prospects for Faculty in the Arts and Sciences. Princeton, NJ: Princeton University Press.

Mann, Sheilah. 1990. “Finding Jobs: Place-

\section{References}

ment of Political Scientists, 1988." PS: Political Science and Politics, September, pp. 495-99.

Mooney, Carolyn J. 1990. "Faculty Job Market Slowly Improving, Evidence Indicates." The Chronicle of Higher Education, April 18.

\section{Affirmative Action: Women and Minorities in the Profession}

\section{Michael Brintnall \\ American Political Science Association}

From time to time, APSA reports on numbers of women and minorities in the profession and on those active in the Association. ${ }^{1}$ This report draws on information from the annual Survey of Departments and the annual survey of Graduate Students and Faculty in Political Science to report on current numbers of women and minorities actively teaching in four-year and graduate institutions, on those entering, attending, and completing graduate study, and on other recent trends. The analysis looks at total numbers of faculty, full-time faculty, variation by rank, and, as an indicator of senior leadership positions within the profession, numbers holding tenured positions in Ph.D.granting programs. ${ }^{2}$

Women and minorities have made important gains in numbers of faculty positions in political science over the years, as shown in Table 1. In roughly two decades, women have almost doubled their share of faculty positions, African Americans have increased their share by half; Latino faculty have tripled in proportion; and Asians have increased by onethird. ${ }^{3}$ The discipline, nevertheless, remains foremost white and male $(73 \%)$. Figure 1 illustrates numbers of political science faculty by race or ethnicity and by gender. Men predominate among all racial and ethnic groups in political science faculties.

\section{Recent Trends}

The following data examine recent trends affecting women, African American, and Latino faculty and graduate students, for whom data are available. 
TABLE 1.

Faculty by Gender and Race or Ethnicity

\begin{tabular}{ccccccc}
\hline & Total & Women & African American & Latino & Asian & Native American \\
\hline $1990-91$ & 11,875 & 2,231 & 544 & 220 & 445 & 14 \\
$\mathrm{~N}$ & 100 & 19 & 4.6 & 1.9 & 3.7 & .1 \\
$\%$ & 100 & 13 & 3.2 & 1.5 & 3.1 & \\
$\begin{array}{c}1980-81 \\
\%\end{array}$ & 100 & 11 & 3.0 & .5 & $2.8^{*}$ & \\
$1972-73$ & & & & & \\
$\%$ & & 10 & & & & \\
\hline
\end{tabular}

Source: Departmental Survey for listed years. Totals are not provided for 1972-73 and 1980-81 data because these surveys were not adjusted for missing data.

*1974-75 data.

Women comprise $19 \%$ of all faculty teaching full- or part-time. This has increased from $14 \%$ in the mid1980 s, $11 \%$ in the early 1970 s, and perhaps $8 \%$ in $1948 .{ }^{4}$ Women hold $16 \%$ of full-time faculty positions, and $10 \%$ of the tenured positions in doctoral programs. This is shown in Tables 2, 3, and 4.

Trends in graduate student enrollment of women show growing numbers of new students and a one-third increase over the last decade in numbers of women in the graduate school pipeline, rates which are comparable to, but more accelerated than that for men. New Ph.D.s awarded to women have shown slight growth in the decade, in contrast to a decline

\section{FIGURE 1.}

Political Science Faculty by Race or Ethnicity and Gender

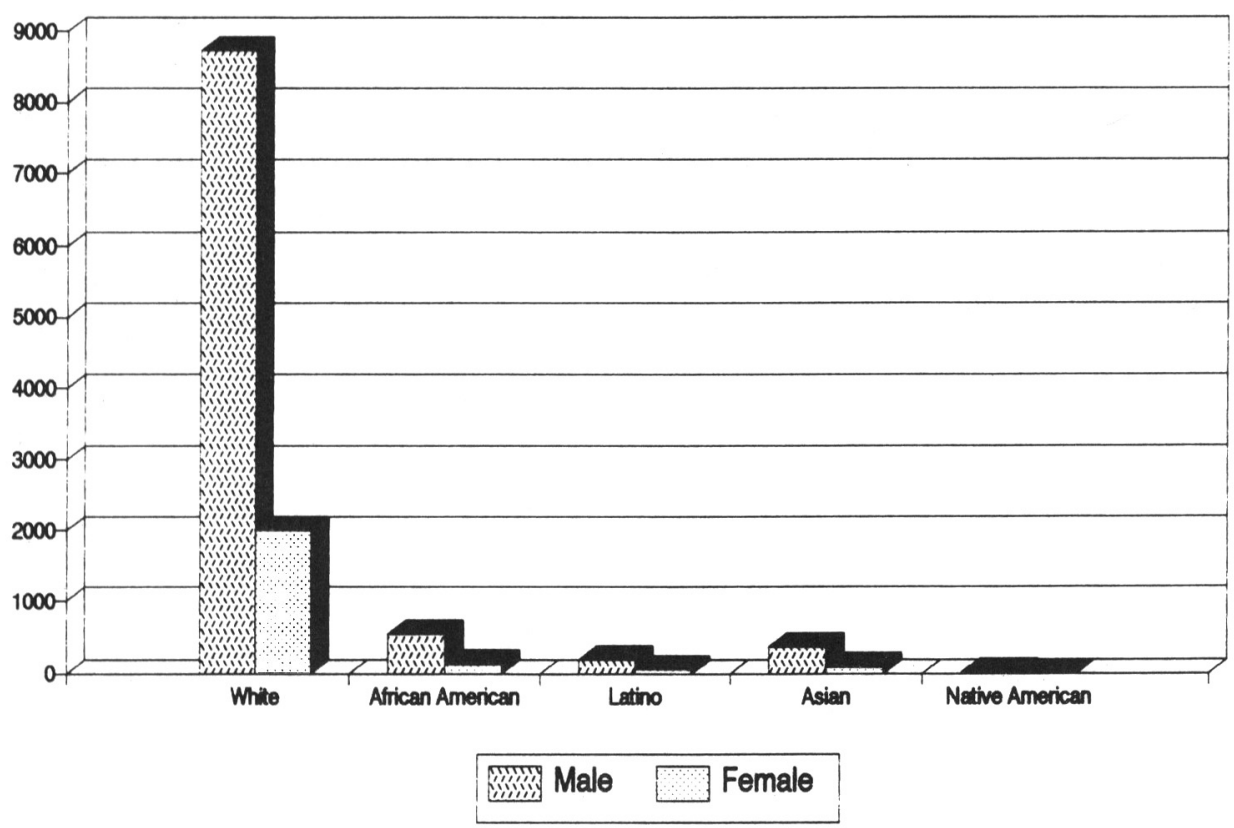

discouraging decade: new enrollments show an increase in the last several years and numbers of students in school is growing. Ph.D. production, however, is still in decline. This is shown in Figure 4 and Table 5.

Latino faculty comprise $2 \%$ of the total professoriate and of full-time faculty, and $1 \%$ of tenured faculty in Ph.D.-granting programs. This compares with just $.5 \%$ of total faculty in the early 1970 s and $1.5 \%$ in 1980. Current data are shown in Tables 2, 3 , and 4. Time series data are not available on Latino students in graduate school; however, as discussed below, data for 1990-91 indicate that Latino students are now entering graduate school at relatively high rates.

\section{Women and Minorities in Graduate School}

Academic change can be a long process. For new groups to enter the professoriate, they must first enter graduate school, where the median chronological time to complete a doctorate in political science is $\mathbf{1 0}$ years. ${ }^{5}$ One measure of the prospects for graduate school classes to increase the proportions of different groups in the professoriate is the ratio of students in graduate school to faculty of that group in the professoriate. Table 6 presents these data.

Table 5 shows the number of students starting graduate school in 1990-91, in graduate school at that time, and earning the Ph.D. that year relative to the total number of faculty in the professoriate for that group. For instance, for women, a number entered graduate school in $1990-91$ equal to about $20 \%(.19)$ of all women faculty now teaching; a number equal to about $90 \%(.88)$ of all women faculty are now in graduate school; and the number of new Ph.D.s is $6 \%$ of all women now in the professoriate.

The most striking findings pertain to Latino students. Relative to their numbers now in the professoriate, Latino students are by far the most numerous in graduate school. A number equal to about one-third of present Latino faculty started graduate study last year, and there are Latino students reported in graduate school at a rate almost equal to the 
TABLE 2.

All Faculty (Full- and Part-Time)

\begin{tabular}{|c|c|c|c|c|c|c|c|c|}
\hline & \multicolumn{2}{|c|}{ All } & \multicolumn{2}{|c|}{ Women } & \multicolumn{2}{|c|}{ African American } & \multicolumn{2}{|c|}{ Latino } \\
\hline & $\mathrm{N}$ & $\%$ of all & $\mathrm{N}$ & $\%$ of all & $\mathrm{N}$ & $\%$ of all & $\mathrm{N}$ & $\%$ of al \\
\hline 1985 & 9,878 & 100 & 1,422 & 14 & 350 & 4 & 143 & 1 \\
\hline 1986 & 9,896 & 100 & 1,458 & 15 & 391 & 4 & 142 & 1 \\
\hline 1987 & 9,905 & 100 & 1,458 & 15 & 436 & 4 & 143 & 1 \\
\hline 1988 & 11,042 & 100 & 1,922 & 17 & 443 & 4 & 183 & 2 \\
\hline 1989 & 11,350 & 100 & 1,927 & 17 & 516 & 5 & 193 & 2 \\
\hline 1990 & 11,592 & 100 & 2,170 & 19 & 525 & 5 & 207 & 2 \\
\hline 1991 & 11,875 & 100 & 2,231 & 19 & 544 & 5 & 220 & 2 \\
\hline
\end{tabular}

TABLE 3.

Full-Time Faculty

\begin{tabular}{|c|c|c|c|c|c|c|c|c|}
\hline & \multicolumn{2}{|c|}{ All } & \multicolumn{2}{|c|}{ Women } & \multicolumn{2}{|c|}{ African American } & \multicolumn{2}{|c|}{ Latino } \\
\hline & $\mathrm{N}$ & $\%$ of all & $\mathrm{N}$ & $\%$ of all & $\mathrm{N}$ & $\%$ of all & $\mathrm{N}$ & $\%$ of all \\
\hline 1985 & 7,992 & 100 & 1,031 & 13 & 277 & 3 & 104 & 1 \\
\hline 1986 & 8,126 & 100 & 1,049 & 13 & 308 & 4 & 111 & 1 \\
\hline 1987 & 8,126 & 100 & 1,086 & 13 & 308 & 4 & 126 & 2 \\
\hline 1988 & 8,571 & 100 & 1,298 & 15 & 350 & 4 & 136 & 2 \\
\hline 1989 & 8,791 & 100 & 1,305 & 15 & 359 & 4 & 138 & 2 \\
\hline 1990 & 8,932 & 100 & 1,486 & 17 & 365 & 4 & 156 & 2 \\
\hline 1991 & 9,260 & 100 & 1,517 & 16 & 379 & 4 & 165 & 2 \\
\hline
\end{tabular}

TABLE 4.

Faculty Holding Tenured Positions in Ph.D. Programs

\begin{tabular}{|c|c|c|c|c|c|c|c|c|}
\hline & \multicolumn{2}{|c|}{ All } & \multicolumn{2}{|c|}{ Women } & \multicolumn{2}{|c|}{ African American } & \multicolumn{2}{|c|}{ Latino } \\
\hline & $\mathrm{N}$ & $\%$ of all & $\mathrm{N}$ & $\%$ of all & $\mathrm{N}$ & $\%$ of all & $\mathrm{N}$ & $\%$ of all \\
\hline 1985 & 1,941 & 100 & 148 & 8 & 41 & 2 & 19 & 1 \\
\hline 1986 & 1,979 & 100 & 153 & 8 & 33 & 2 & 21 & 1 \\
\hline 1987 & 2,011 & 100 & 157 & 8 & 35 & 2 & 21 & 1 \\
\hline 1988 & 2,017 & 100 & 173 & 9 & 34 & 2 & 21 & 1 \\
\hline 1989 & 2,084 & 100 & 186 & 9 & 35 & 2 & 24 & 1 \\
\hline 1990 & 2,084 & 100 & 213 & 10 & 36 & 2 & 28 & 1 \\
\hline 1991 & 2,177 & 100 & 215 & 10 & 51 & 2 & 28 & 1 \\
\hline
\end{tabular}

size of the current professoriate.

Women are also entering and attending graduate school in relatively high numbers-double the rate of males by this measure. This high rate of attendance is not evident at the point of actual $\mathrm{Ph}$.D. awards, however. African American students are entering and attending graduate school at rates only very slightly above those for all students, however, suggesting that the opportunity for increasing the proportions of African Americans in the professoriate in the short term is constrained.

\section{Trends in Rank}

Another important dimension to the situation of women and minority faculty is their distribution by rank. An important indicator of the success of different groups of faculty in achieving leadership positions in the profession is their numbers in the higher ranks. The following information shows trends in the distribution of groups of faculty across ranks over the last seven academic years.

First of all, as a matter of reference, for male faculty half hold the rank of full professor, as shown in Figure 5. The number of male full professors has been growing, while numbers of associate professors has declined. This is consistent with other evidence widely cited regarding the aging of the faculty, and it is the basis for projections of greatly

TABLE 5.

Ph.D. Programs-Graduate Students and Faculty Cumulative Data, 1980-91*

\begin{tabular}{|c|c|c|c|c|c|c|c|c|c|c|c|c|c|c|}
\hline \multirow{3}{*}{$\begin{array}{l}\text { School } \\
\text { Year } \\
\text { Ending }\end{array}$} & \multicolumn{4}{|c|}{ Student Degrees and Admissions } & \multicolumn{9}{|c|}{ Women, African American, and Latino Students } & \multirow{3}{*}{$\begin{array}{c}\text { No. of } \\
\text { Foreign } \\
\text { Students } \\
\text { Now in } \\
\text { Ph.D. Program } \\
\end{array}$} \\
\hline & \multirow{2}{*}{$\begin{array}{l}\text { Average No. } \\
\text { of Ph.D.s } \\
\text { Granted } \\
\text { Annually } \\
\text { Last } 3 \text { Years } \\
\end{array}$} & \multirow{2}{*}{$\begin{array}{c}\text { No. of } \\
\text { Students } \\
\text { Now in } \\
\text { Ph.D. Program } \\
\end{array}$} & \multirow{2}{*}{$\begin{array}{l}\text { No. Applying } \\
\text { to Enter } \\
\text { Ph.D. Program } \\
\text { in Fall }\end{array}$} & \multirow{2}{*}{$\begin{array}{c}\text { No. Accepted } \\
\text { Who Started } \\
\text { Ph.D. Work } \\
\text { in Fall }\end{array}$} & \multicolumn{3}{|c|}{ Total Ph.D.s in Last 3 Years } & \multicolumn{3}{|c|}{ No. Now in Ph.D. Program } & \multicolumn{3}{|c|}{ No. Starting Ph.D. in Fall } & \\
\hline & & & & & Women & $\begin{array}{l}\text { African } \\
\text { American } \\
\end{array}$ & Latino & Women & $\begin{array}{l}\text { African } \\
\text { American } \\
\end{array}$ & Latino & Women & $\begin{array}{l}\text { African } \\
\text { American } \\
\end{array}$ & Latino & \\
\hline 1980 & 735 & 5,796 & 5,236 & 1,071 & 346 & 143 & - & 1,397 & 424 & - & 319 & 107 & - & 1,187 \\
\hline 1981 & 712 & 5,756 & 4,982 & 1,094 & 369 & 130 & - & 1,415 & 384 & - & 346 & 110 & - & 1,238 \\
\hline 1982 & 628 & 5,492 & 5,531 & 1,011 & 365 & 101 & - & 1,347 & 330 & - & 312 & 76 & - & 1,242 \\
\hline 1983 & 638 & 5,273 & 5,187 & 1,019 & 361 & 97 & - & 1,371 & 306 & - & 308 & 72 & - & 1,271 \\
\hline 1984 & 647 & 5,054 & 4,893 & 1,026 & 357 & 94 & - & 1,394 & 283 & - & 303 & 68 & - & 1,301 \\
\hline 1985 & 614 & 5,495 & 5,809 & 996 & 339 & 87 & - & 1,440 & 297 & - & 277 & 54 & - & 1,456 \\
\hline 1986 & 613 & 5,882 & 5,934 & 1,121 & 420 & 117 & - & 1,643 & 350 & - & 344 & 64 & - & 1,369 \\
\hline 1987 & 506 & 5,501 & 7,215 & 1,095 & 381 & 91 & - & 1,530 & 267 & - & 297 & 46 & - & 1,499 \\
\hline 1988 & 591 & 5,984 & 8,170 & 1,154 & 419 & 96 & - & 1,684 & 256 & - & 368 & 56 & - & 1,658 \\
\hline 1989 & 571 & 6,542 & 9,013 & 1,384 & 426 & 81 & - & 1,859 & 303 & - & 429 & 85 & - & 1,853 \\
\hline 1990 & 575 & 6,826 & 9,392 & 1,309 & 381 & 78 & - & 2,022 & 337 & - & 428 & 67 & - & 1,684 \\
\hline 1991 & 554 & 6,453 & 11,243 & 1,315 & 399 & 86 & 33 & 1,973 & 300 & 215 & 415 & 71 & 74 & 1,516 \\
\hline
\end{tabular}

*These numbers are adjusted for missing data to reflect totals for the profession as a whole. 
TABLE 6.

Ratios of Graduate Students to Existing Faculty, by Faculty Groups

\begin{tabular}{lccc}
\hline Group & $\begin{array}{c}\text { Students Entering } \\
\text { Programs }\end{array}$ & $\begin{array}{c}\text { Students Now in } \\
\text { Ph.D. Programs }\end{array}$ & $\begin{array}{c}\text { New Ph.D.s } \\
\text { Awarded }\end{array}$ \\
\hline All & .11 & .54 & .05 \\
Men & .09 & .46 & .05 \\
Women & .19 & .88 & .06 \\
African American & .13 & .55 & .05 \\
Latino & .34 & .98 & .05 \\
\hline
\end{tabular}

\section{FIGURE 2.}

\section{Male Graduate Students}

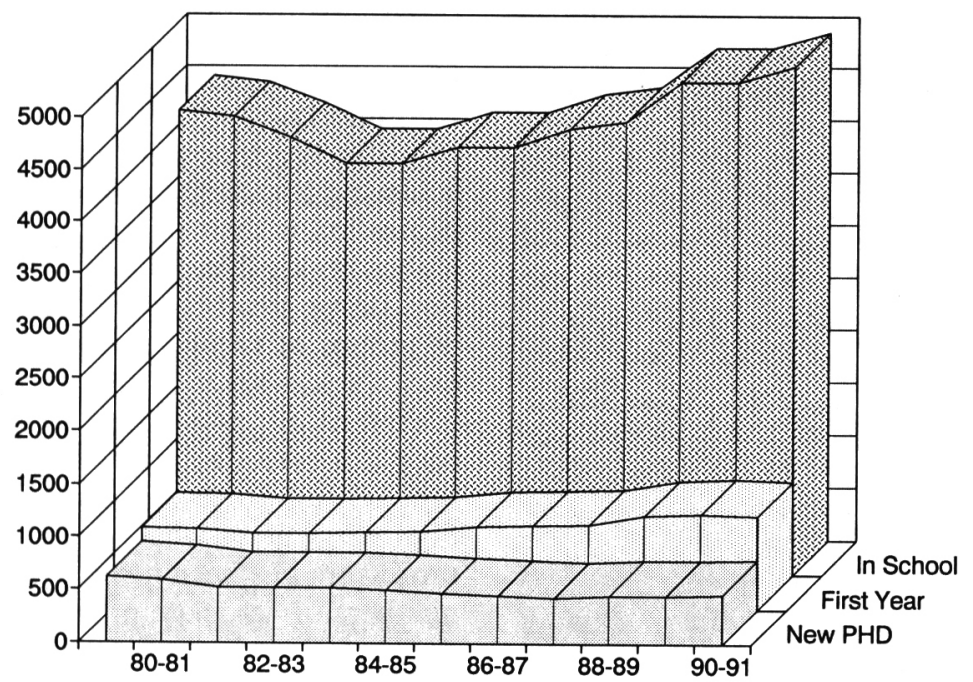

FIGURE 3.

Female Graduate Students

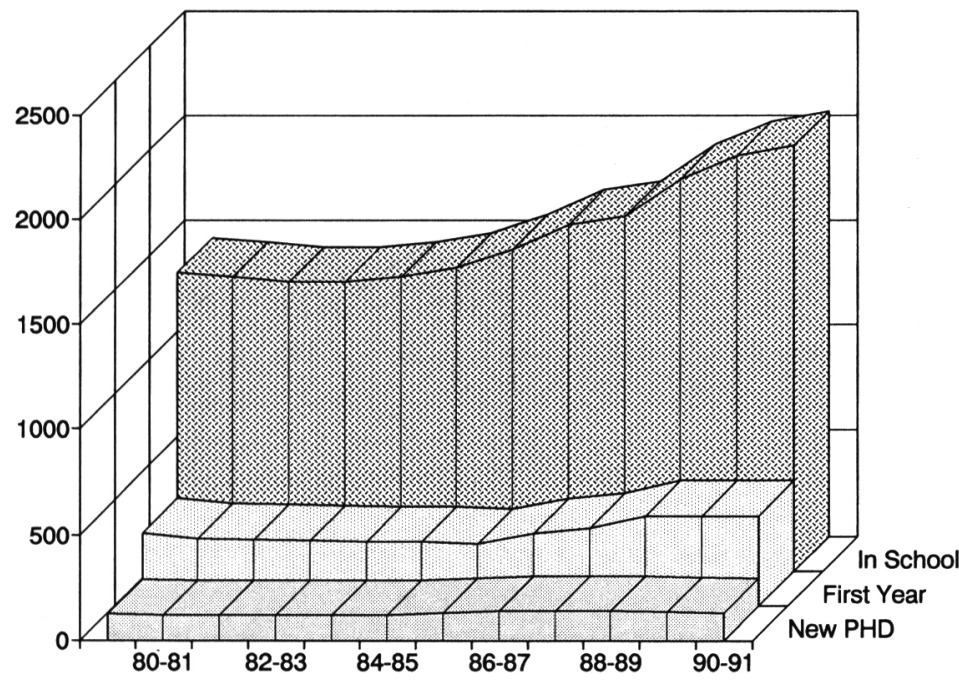

increasing numbers of retirements later this decade.

In contrast, while women and minority faculty are preponderantly in the lower ranks, all of these groups have made noticeable gains in numbers in the senior rank in the last several years. Women faculty have gained in absolute numbers in all ranks, with each rank poised to sustain growth in the next. These data show great promise for women to continue to gain leadership roles in the profession.

Numbers of African American faculty have also shown recent gains at the associate and full professor level, probably reflecting the professional maturing of scholars earning their degrees in the 1970s and early 1980s. But they have levelled off at the ranks of instructor and assistant professor. Latino faculty show growth at the highest rank, and at the lowest. In examining Figures 6, 7, and 8, note that numbers of full professors are shown in the front of the graph, not the back as in Figure 5.

\section{Conclusions}

Substantial gains in numbers of women and minorities in the political science professoriate have been made in recent years, and they are continuing. Efforts to support these advances have encouraged recruitment of women and minorities. Efforts are continuing through the Minority Identification Project, the Ralph Bunche Summer Institute, the Initiative for an institute for Latino students, the Minority Graduate Fellowship program, and the on-going work of the committees on the status of women, of blacks, and of Latinos in the profession.

One factor not explored in this study is rates of attrition of women and minorities in graduate school or later in professional careers in political science. Other fields have found this to be a concern, and increasingly there are recommendations for increased mentorship and support of students after entrance into graduate school and later the profession as well as encouragement beforehand. Attrition may be a factor that accounts in part for the relatively lower proportions of women and minority faculty in higher ranks, an 
FIGURE 4.

African American Graduate Students

\section{AFRICAN AMERICAN GRADUATE STUDENTS}

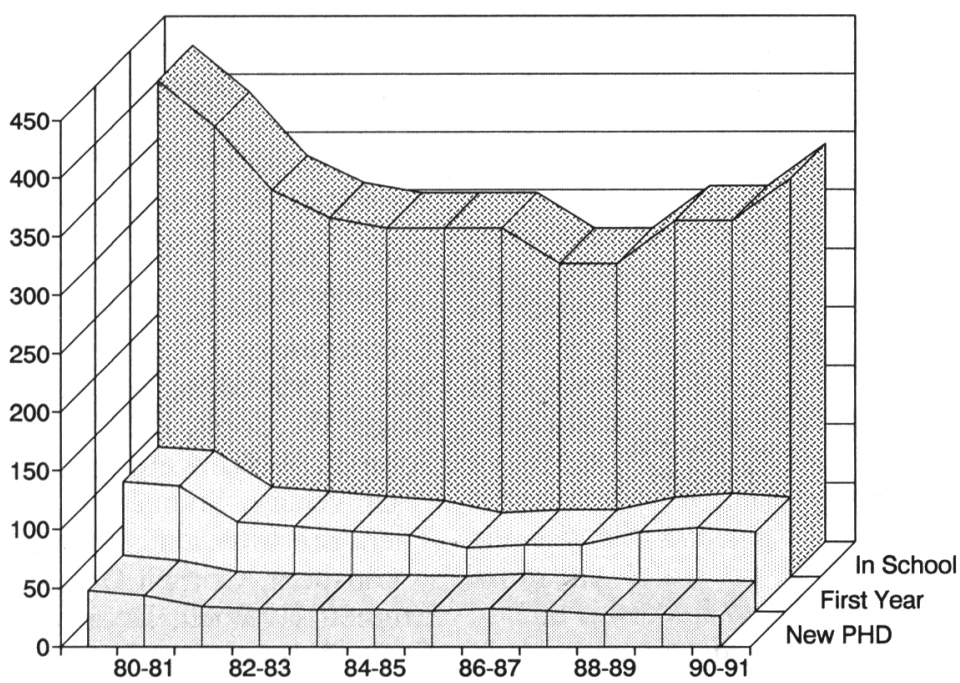

FIGURE 5.

Male Faculty-Full-time, by Rank

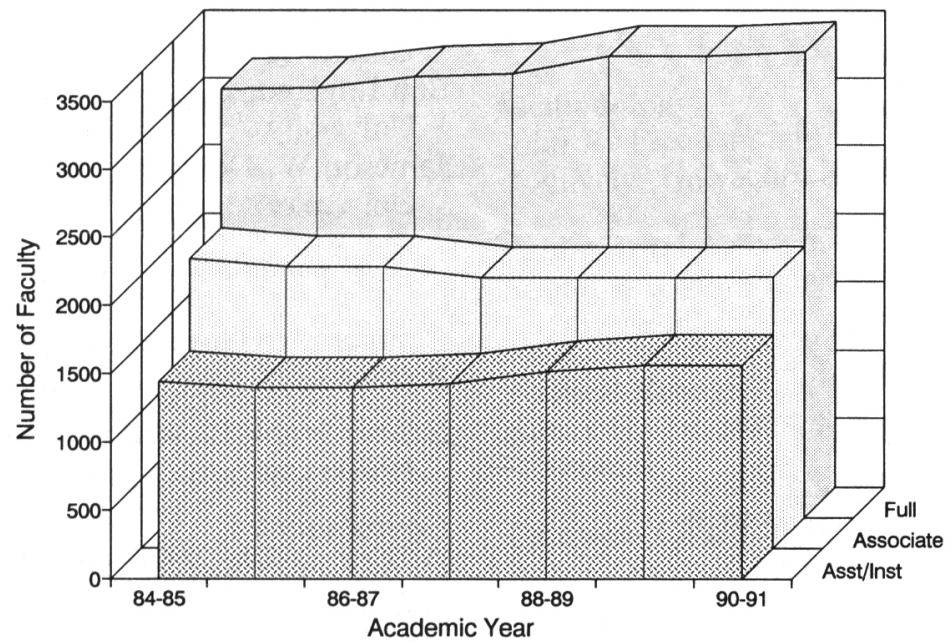

FIGURE 6.

Female Faculty-Full-time, by Rank

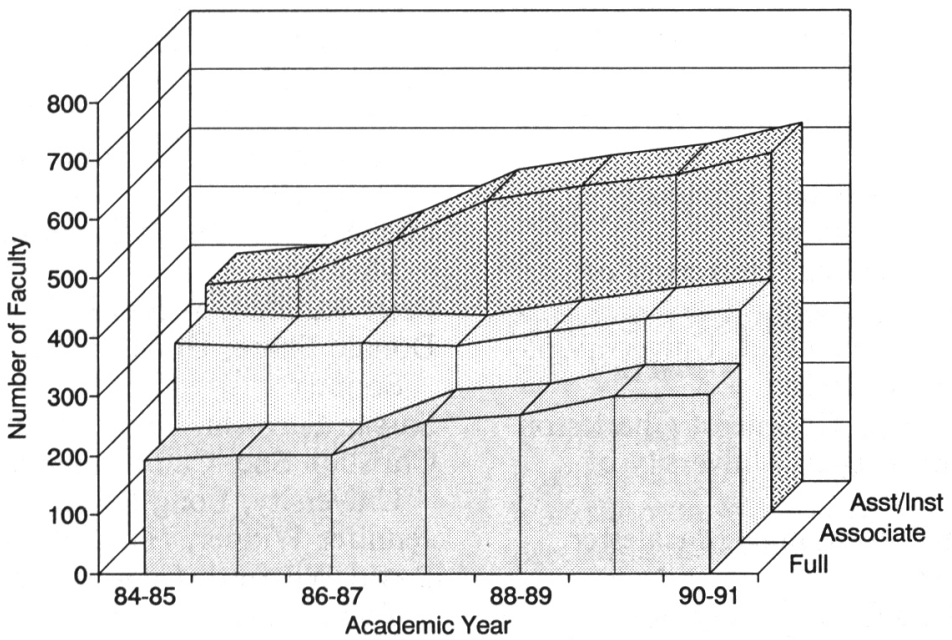

the relatively lower ratios of graduate students earning Ph.D.s than entering graduate school, especially among women.

Subsequent reports in $P S$ will explore issues such as this, as well as the expanding role that women and minorities now play in the work of APSA itself.

\section{Notes}

1. Some of the earlier studies include Robert J-P. Hauck, 1984, "Affirmative Action: Recognition of Women and Minorities in the Association," PS (Fall), pp. 809-10; N.A., 1989. "Affirmative Action in the 80s: Recognition of Women and Minorities in the APSA," PS (March), pp. 103-4; and Departmental Services Program, Survey of Departments, APSA, for various years since 1971-72. But see the following note regarding information about comparability of data. There is also a paper forthcoming in $P S$ by the Committee on the Status of Women on improving the status of women in political science.

2. Data on faculty are adjusted from the raw data in the departmental and graduate surveys in two ways. First data are adjusted for non-responses by separately weighting for non-response rates each type of institution responding (Ph.D.-granting, M.A.-granting, four-year degree, and four-year programs in which political science is combined with other fields). This provides estimates for the professoriate as a whole. Then the annual data were smoothed using first order running medians of three.

For these two reasons most data here are not exactly comparable to raw numbers reported in past Departmental Surveys and some $P S$ reports on historical trends. However, the underlying data and its basic forms are the same.

3. Data on numbers of Native Americans have been collected since 1981, but reported numbers have fluctuated wildly from 2 to 126 and no time series is attempted here.

4. The 1948 data actually refer to members of APSA, not faculty per se. They were compiled by Phyllis G. Wherley and reported in an appendix to the 1948 Directory of the Association.

5. National Academy of Sciences, Summary Report 1990: Doctorate Recipients from United States Universities, National Academy Press, 1991.

\section{The Political Science Course Syllabi Collection Project}

The APSA is initiating a program to collect and distribute exemplary syllabi for political science courses. The collections are meant to be a 